Doi: $10.4274 /$ Vhd. 18.08

\title{
Hepatit B Virüsü ile Enfekte Hastaların Hastalık Hakkında Bilgi Düzeylerinin Değerlendirilmesi
}

\author{
Evaluation of the Knowledge Level of the Patients Infected By HBV About Their Disease
}

\author{
Rahmet GÜNER1, Ayşe KAYA KALEM1, Imran HASANOĞLU1, Şiran KESKE2, Tümer GÜVEN1, \\ Gül Ruhsar YILMAZ1, Mehmet Akın TAŞYARAN3 \\ ${ }^{1}$ Ankara Atatürk Eğitim ve Araştırma Hastanesi ,Enfeksiyon Hastalıkları ve Klinik Mikrobiyoloji Kliniği, Ankara, Türkiye \\ 2Polatı Duatepe Devlet Hastanesi, Enfeksiyon Hastalıkları ve Klinik Mikrobiyoloji, Ankara, Türkiye \\ ${ }_{3}$ Yıldırım Beyazı Ünitersitesi Tıp Fakültesi Enfeksiyon Hastalıkları ve Klinik Mikrobiyoloji Kliniği, Ankara, Türkiye
}

\begin{abstract}
ÖZET
Amaç: Hepatit B virüs (HBV) enfeksiyonundan korunmada, aşılama ve eğitim çalışmalarının rolü çok büyüktür. Çalışmamızda, HBV ile enfekte hastalarımızın, hastalıkları ile ilgili bilgi düzeylerinin değerlendirilmesi amaçlanmıştır.

Gereç ve Yöntemler: Hastalara 27 sorudan oluşan anket bire bir doldurtuldu. Istatistiksel analiz için SPSS 15,0 for Windows programı kullanıldı.

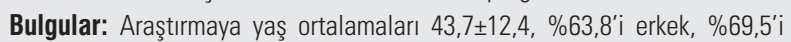
hepatit B taşıyıcıIı, \%30,5'i kronik hepatit B enfeksiyonu tanılı 105 vaka dahil edildi. Vakaların \%20'si kan bağıșı sırasında, \%16,2'si ise ameliyat öncesi yapılan rutin tetkiklerde hepatit B hastası olduğunu öğrenmişti. Bulaş yolu olarak en sık kan yolu ve cinsel temas sorumlu tutulurken, öpüşmek hapşırmak, bardak, tabak çatal gibi eşyaların birlikte kullanımı, hasta ile aynı evde yaşamanın da bulaşta sorumlu olabileceği hastaların bir kısmı tarafından ifade edilmişti. Olguların \%85,7'si siroz, \%65,7'si karaciğer kanseri, \%61,9'u karaciğer yetmezliği gibi hastalığın komplikasyonları hakkında bilgi sahibiydi. Hastaların eğitim düzeyleri ile hastalığın olası sonuçlarının bilinmesi arasında istatistiksel anlamlı fark tespit edilmedi. Vakaların \%33.3' ü HBV enfeksiyonundan korunmanın bir yolu olarak gıdaların bol su ile yıkanması gerektiğine inanmaktaydı ve bu yanlış bilgiyle eğitim düzeyi arasında bir paralellik yoktu. Hastaların \% 72,9'u HBV enfeksiyonunun tedavi edilebilir bir hastalık olduğunu, \%78'i ise tedavinin amacının hastalığın ilerlemesini durdurmak olduğunu belirtti. Olguların \%13,8'i bitkisel ilaçların hastalığa çözüm olabileceğini düşünüyordu.

Sonuç: HBV ile enfekte hastaların hastalık konusundaki bilgi düzeyinin eğitim düzeyine bakmaksızın yetersiz olduğu açıkça görülmektedir. Konu hakkında bilgilendirme çalışmalarına ağırlık verilmesi gerek hastaların tedavi ve takibi, gerekse hastaların sosyal hayatlarındaki olumsuzluklarla başa çıkmaları için son derece önemlidir. (Viral Hepatit Dergisi 2012; 18(1): 29-33)

Anahtar Kelimeler: Hepatit B virüs enfeksiyonu, bilgi düzeyi, korunma, bulaş yolları
\end{abstract}

\begin{abstract}
Objective: Vaccination and education play an important role in prevention of hepatitis $B$ virus (HBV) infection.

Materials and Methods: In our study, a survey consisting of 27 questions was filled out face to face to evaluate the knowledge level of our patients, who were infected with HBV. SPSS 15.0 for Windows was used for statistical analysis. Results: A total of 105 patients with average age $43.7 \pm 12.4$ participated in the survey. $63.8 \%$ of the participants were male, $69.5 \%$ were hepatitis B carrier and $30.5 \%$ were chronic hepatitis B. $20 \%$ of the patients became aware of their disease during blood donation and $16.2 \%$ have been informed during pre-surgical routine tests. Most attributed transmission routes were blood and sexual contact, however kissing, sneezing, common use of kitchenettes like glass, plate, fork, sharing the house with infected patient were the other ways for transmission. $85.7 \%, 65.7 \%$ and $61.9 \%$ of the patients had information about some of the complications of HBV like cirhosis, liver cancer and liver failur, respectively. There was no statistically significant relation between education level of the patients and their awareness about possible consequences of the disease. $33.3 \%$ of the cases believed that scouring the food was one of the ways of preventing the disease and there was no relation between this wrong belief and education level of the patients. $72.9 \%$ of the patients told that the disease was curable and $78 \%$ of them reported that the aim of the treatment was to stop the progression of the disease. $13.8 \%$ of the patients thought that herbal treatments might be a solution in treatment of the disease.

Conclusion: The knowledge level of the patients infected by HBV is obviously insufficient regardless of the patients' education level. It is extremely important to concentrate on catch-up works for society not only for the patients to deal with the negative consequences of the disease on their social life, but also for follow-up and treatment of the patients. (Viral Hepatitis Journal 2012; 18(1): 29-33)
\end{abstract}

Key words: Hepatitis B infection, knowledge level, prevention, transmission route

Yazışma Adresi/Address for Correspondence: Dr. Ayşe Kaya Kalem, Ankara Atatürk Eğitim ve Araştırma Hastanesi, Enfeksiyon Hastalıkları ve Klinik Mikrobiyoloji Kliniği, Ankara, Türkiye Tel.:+90 5063009586 E-mail: dr.aysekaya09@hotmail.com Received/Geliș tarihi: 20.03.2012 Accepted/Kabul tarihi: 14.04.2012 


\section{Giriş}

Hepatit B virüs (HBV) enfeksiyonu halen tüm dünyada önde gelen sağlık sorunlarından biridir. Dünya nüfusunun yaklaşık 1/3'ü HBV ile enfektedir. Değişik bölgelerde yapılan prevalans ve hastalık sonuçları ile ilgili çalışmalar HBV'nin tüm siroz vakalarının \%30'undan, tüm hepatoselüler kanser (HSK) vakalarının ise \%53'ünden sorumlu olduğunu göstermektedir $(1,2)$. Enfeksiyonun dünyadaki dağılımı, alınma yaşı, bulaş yolları gibi birçok faktör nedeni ile, farklı coğrafik bölgelerde oran değişmektedir.

Ülkemizde, HBV enfeksiyonu endemiktir ve horizontal geçiş ön plandadır. Bu nedenle enfeksiyondan korunmada aşılama ve eğitim çalışmalarının rolü büyüktür. Ülkemizde ve dünyada yapılan pek çok çalışmada tıp fakültesi öğrencilerinin, diş doktorlarının, sağlık çalışanlarının eğitim düzeyi değerlendirilmiş ve konu ile ilgili bilgi düzeylerinin düşük olduğu saptanmıştır (37). Yaptığımız anket çalışmasında, HBV ile enfekte hastalarımızın, hastalığın tanımı, geçiş yolları, risk faktörleri, korunma yöntemleri ve hastalığın sonuçları konusundaki bilgi düzeylerinin değerlendirilmesi hedeflenmiştir.

\section{Gereç ve Yöntem}

HBV ile enfekte 105 hastadan, HBV enfeksiyonu tanımı, geçiş yolları, risk faktörleri, korunma yöntemleri, hastalığın sonuçları ile ilgili 27 sorudan oluşan ankete cevap vermeleri istendi. Anket katılımcılarla yüz yüze soru cevap şeklinde yapıldı. Istatistiksel analiz için SPSS 15.0 for Windows programı kullanıldı. Kategorik değişkenlerin karşılaştırılmasında Ki-Kare testi, koşul sağlanmayan verilere Monte-Carlo simülasyonu uygulandı. Istatistiksel anlamlılık düzeyi $p<0,05$ olarak kabul edildi.

\section{Bulgular}

Araştırmaya yaş ortalamaları $43,7 \pm 12,4$ yıl olan hepatit B enfeksiyonu tanılı 67 erkek ve 38 kadından oluşan 105 hasta dahil edildi. Çalışmaya dahil edilen hastaların \%69,5'i hepatit B taşıyıcısı, \%30,5'i kronik hepatit B hastasıydı. \%43,1'i ilkokul, $\% 27,4$ 'ü lise, \%16,7'si üniversite, \%10,8'i ortaokul mezunu, $\% 2$ 'si okur yazardı. Hastaların \%28,2'si ev hanımı, \%22,5'i işçi, \%21,5'i serbest meslek, \%12,8'i emekli, \%12'si memur, \%3'ü

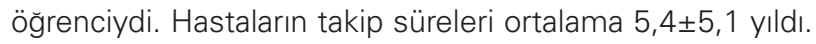

Hastalar en sık (\%20) kan bağışı sırasında Hepatit B hastası olduğunu öğrenmişti. Aile bireylerinde de bilinen HBV enfeksiyonu \%38,2 oranındaydı (Tablo 1).

Hastaların \%56,2'si hepatit C, \%45.7'si hepatit A virüsünü bildiğini belirtti. Hepatit D $(\% 6,7)$ ve hepatit $E(\% 2,9)$ virüslerini bilen hasta sayısı düşüktü. Diğer virüslerin bilinmesi ile eğitim düzeyleri arasında istatistiksel olarak anlamlı bir ilişki saptanmadı.

Hastalar hepatit B virüs enfeksiyonunun en çok kan yolu $(\% 90,5)$, cinsel temas $(\% 76,2)$ ve diş tedavisi $(\% 70,5)$ ile bulaştığını düşünüyorlardı (Tablo 2). Ortaokul, lise ve üniversite mezunlarının hepatit B virüsünün kan yolu, diş tedavisi ve akupunktur, dövme gibi işlemler ile bulaştığını bilme oranları, okur-yazar ve ilkokul mezunlarına göre daha yüksekti (sırasıyla $p=0,01, p=0,01, p=0,01)$. Diğer bulaşma yolları hakkındaki bilgi düzeyi ile ilgili olarak, eğitim grupları arasında anlamlı fark saptanmadı.

Hastalar hepatit B hastalığı ile ilgili bilgilerini en çok doktorlarından (\%79) öğreniyorlardı. \%24,5'i internet yolu ile bilgi edinmişti.

Hepatit B enfeksiyonunun seyri hakkında hastaların bilgileri araştııılığında, hastalığın ilerlemesi durumunda karaciğer

Tablo 2. Hepatit B virüsünün olası bulaşma yolları

\begin{tabular}{lcc}
\hline & Sayı (n) & Yüzde (\%) \\
\hline Kan yolu ile & 95 & 90,5 \\
Cinsel temas ile & 80 & 76,2 \\
Diş tedavisi ile & 74 & 70,5 \\
Enjektör batması ile & 59 & 56,2 \\
Doğum sırasında anneden bebeğe & 55 & 52,4 \\
Akupunktur, dövme, piercing sırasında kullanılan aletler ile & 50 & 47,6 \\
Berberde traş olma ile & 49 & 46,7 \\
Hasta kişinin bardak, çatal, kaşık gibi & 27 & 25,7 \\
eşyalarını kullanılması ile & & \\
Öpüşme, hapşırma ile & 18 & 17,1 \\
Sivrisinek ısırması ile & 17 & 16,2 \\
Balgam, ter, gözyaşı, anne sütü ile & 16 & 15,2 \\
Hasta ile aynı evde yaşama & 9 & 8,6 \\
Tokalaşma ile & 8 & 7,6 \\
Hava yolu ile & 4 & 3,8 \\
\hline
\end{tabular}

Tablo 1. HBV ile enfekte olduğunu öğrenme yolu

\begin{tabular}{lcc} 
& Sayı (n) & Yüzde (\%) \\
\hline Kan bağışı sırasında & 21 & 20 \\
Ameliyat öncesi yapılan tetkiklerde & 17 & 16,2 \\
Kendi isteği ile yapılan tetkikler sırasında & 15 & 14,3 \\
Yakınında tespit edilmesi üzerine yapılan tetkikler sırasında & 12 & 11,4 \\
Iş başvurusunda & 4 & 3,8 \\
Diş doktoruna başvuruda & 2 & 1,9 \\
Sarlık nedeni ile & 2 & 1,9 \\
Diğer & 32 & 30,5 \\
Toplam & 105 & 100 \\
\end{tabular}


yetmezliği, siroz ve kansere dönüşebileceğini \%85,7'si bilmekteydi (Tablo 3). Hepatit B hastalığı ilerlediğinde görülebilecek komplikasyonların bilinme oranlarının eğitim düzeyi ve cinsiyete göre istatistiksel olarak anlamlı farklılık göstermediği saptandı.

HBV enfeksiyonundan korunmada diş fırçası, tırnak makası gibi kişisel eşyaların ayrılması $(\% 75,2)$ ön planda gerekli görülen önlemlerdi (Tablo 4). Ilginç olarak hastaların \%33,3'ü gıdaları bol su ile yıkamanın hastalıktan korunmada önemli olduğunu ifade etmişlerdi. Korunma yolları arasında kan ve vücut sıvıları ile temastan kaçınmanın, kişisel hijyen araçlarının (diş fırçası gibi) ayrımasının önemli olduğu, okur yazar ve ilkokul mezunlarına göre diğer eğitim düzeylerinde daha iyi bilinmekteydi $(p=0,03$, $\mathrm{p}=0,02$ ).

Anketimizde sorulan diğer sorulara verilen yanıtlar Tablo 5'te özetlenmiştir. Buna göre hastaların bir çoğu HBV enfeksiyonunun tedavi edilebilir olduğunu, aile bireylerinin de tarandığını ifade etmişlerdir.

Hepatit B hastalığında tedavi amacının, hastalığın ilerlemesini durdurmak olduğunu hastaların \%78'i, siroza gidişi

Tablo 3. HBV enfeksiyonunun seyri ile ilgili bilgi düzeyi

\begin{tabular}{lcc}
\hline & Sayı (n) & Yüzde (\%) \\
\hline HBV enfeksiyonu; & & \\
Karaciğer sirozuna sebep olabilir & 90 & 85,7 \\
Karaciğer kanserine sebep olabilir & 69 & 65,7 \\
Karaciğerde yetmezlik nedeni olabilir & 65 & 61,9 \\
Ölüme sebep olabilir & 61 & 58,1 \\
Sarlığa sebep olabilir & 30 & 28,6 \\
Bilmiyorum & 6 & 5,7 \\
\hline
\end{tabular}

Tablo 4. HBV enfeksiyonundan korunma yolları hakkındaki bilgiler

\begin{tabular}{lcc}
\hline & Sayı (n) & Yüzde (\%) \\
\hline Diş fırçası, tırnak makası gibi kişisel eşyaların ayrılması & 79 & 75,2 \\
Aşı olmak & 67 & 63,8 \\
Tek eşli cinsel yaşam & 67 & 63,8 \\
Prezervatif kullanmak & 61 & 58,1 \\
Enfekte kişilerin kan ve vücut sıvılarından korunma & 56 & 53,3 \\
Gıdaları bol su ile yıkamak & 35 & 33,3 \\
\hline
\end{tabular}

Tablo 5. HBV enfeksiyonu hakkında diğer yanıtlar

\begin{tabular}{lcc}
\hline & $\begin{array}{c}\text { Sayı } \\
\text { (evet cevabı verenler / } \\
\text { soruya cevap verenler) } \\
\text { (\%) }\end{array}$ & Yüzde \\
\hline Aile bireylerinin taranması gerekli midir? & $93 / 97$ & 95,8 \\
Hepatit hastalarının yakınları da risk altında mıdır? & $71 / 95$ & 74,7 \\
HBV enfeksiyonu tedavi edilebilir bir hastalık mıdır? & $70 / 96$ & 72,9 \\
HBV enfeksiyonunun tedavisinde diyet uygulanmalıdır & $48 / 89$ & 53,9 \\
HBV enfeksiyonu kendiliğinden düzelebilir & $15 / 89$ & 16,08 \\
Bitkisel ilaçlar hastalığa çözüm olabilir & $13 / 94$ & 13,8 \\
Sigara ve alkolden kaçınılmalıdır & $14 / 105$ & 13,3 \\
\hline
\end{tabular}

önlemek olduğunu \%47,6'sı, karaciğer yetmezliğinden korunmak olduğunu \%31,4'ü, hastalığı tamamen ortadan kaldırmak olduğunu \%29,5'i belirtmiştir.

\section{Tartışma}

Çalışmamızda HBV ile enfekte, sosyal ve iş yaşantılarında çeşitli sıkıntılarla karşı karşıya kalan hastalarımızın konu ile ilgili bilgi düzeylerini ölçmeyi hedefledik. HBV enfeksiyonu ile mücadelede sadece sağlık çalışanlarının değil tüm toplumun, özellikle de HBV ile enfekte bireylerin ve yakınlarının HBV enfeksiyonunun bulaş ve korunma yolları hakkında bilgilendirilmesi çok önemlidir. Bu sayede hem hastaların hem de yakınlarının doğru bilgilenimi sağlanarak, yersiz kaygıları giderilmiş olur. Ülkemizde ve literatürde bu konu ile ilgili çalışmalar genellikle sağlık çalışanlarında yapılmış olup, toplumun diğer kesimlerinde yapılmış çalışma sayısı sınırlıdır.

Ülkemizde yakın zamanda yayınlanmış olan çok merkezli bir çalışmada saptanan epidemiyolojik özellikler ile çalışmamız sonuçları paralel bulunmuştur. Çelen ve arkadaşlarının çalışmasında da hasta populasyonunun çoğunluğunu erkeklerin oluşturduğu, aile bireylerinde hastalığın saptanma oranının \%22,4 olduğu belirtilirken, Realist grubunca bildirilen bir başka çok merkezli çalışmada aile öyküsü \%40 olarak saptanmıştır $(8,9)$.

Vancouver-Richmond'da yaşayan Çinli ve Güneydoğu Asyalılar'da yapılan çalışmada katılımcıların, \%68'i HBV'den haberdar olduklarını ifade etmişler, ancak \%60'dan fazlası HBV ile siroz ve kanser ilişkisini bilememişlerdir. HBV enfeksiyonu hakkında bilgi düzeyinin, ileri yaş, eğitim düzeyi ve sağlık eğitiminde medya kullanımı ile arttığı gösterilmiştir (10).

Tablo 6. Farklı çalışma verileri ile çalışmamız sonuçlarının karşılaştırması

\begin{tabular}{|c|c|c|c|}
\hline & aynak no.20 & Kaynak no. 21 & Çalışmamız \\
\hline \multicolumn{4}{|l|}{ HBV enfeksiyonunun bulaş yollarl; } \\
\hline Kan yolu & 14 & 97 & 90,5 \\
\hline Cinsel ilişki & 5,8 & 68 & 76 \\
\hline Diş tedavisi & - & 60,4 & 70,5 \\
\hline Ortak enjektör kulanımı & 6,5 & 61,3 & 56 \\
\hline Anneden bebeğine doğumda & 5,3 & 72 & 52,4 \\
\hline Ortak traş bıçağı, jilet kullanımı & 6,5 & 72,8 & 46,7 \\
\hline $\begin{array}{l}\text { Manikür, pedikür aletlerinin } \\
\text { ortak kullanımı }\end{array}$ & 6,5 & 60,7 & 46,7 \\
\hline $\begin{array}{l}\text { Bardak, kaşık, çatal gibi eşyaların } \\
\text { ortak kullanımı ile }\end{array}$ & 93,8 & 44,9 & 25,7 \\
\hline Öksürükle & - & 29,4 & 17 \\
\hline Böcek sokması ile & - & 38 & 16 \\
\hline Öpüşmek ile & - & 24,5 & 17 \\
\hline $\begin{array}{l}\text { Tıraş bıçağı, jilet, makas gibi aletlerin } \\
\text { ayrı kullanılması ile hastalıktan korunulu }\end{array}$ & ulur & 64,7 & 75 \\
\hline Aşllama ile hastalıktan korunulur & - & 73,7 & 63.8 \\
\hline $\begin{array}{l}\text { Kondom kullanımı ile } \\
\text { hastalıktan korunulur }\end{array}$ & - & 65 & 58 \\
\hline HBV hastalığının spesifik diyeti yoktur & - & 40,9 & 46 \\
\hline
\end{tabular}


Katılımcıların birçoğunun yanlış bildiği sivrisinek ısırması, anne sütü, balgam, ter, gözyaşı, öpüşmek, hapşırmak, hava yolu, tokalaşma ile hastalığın bulaştığı yönündeki cevaplar toplumdaki yersiz kaygıların, bu hastaların sosyal hayatta yaşadıkları sıkıntıların kaynağını oluşturmaktadır. Lise öğrencileri ile yapılan bir anket çalışmasında, en yüksek bulaş yolu, kan yolu $(\% 84,9)$ olarak tanımlanırken, \%29,6'sı bardak, tarak veya elbiseden, \%30,5'i tükrükten ve \%31,5'i böcek sokması ile etkenin bulaşabileceğini söylemiştir (11). Bizim çalışmamızda da bu yolların bulaşta sorumlu olabileceğini söyleyenlerin oranı azımsanamayacak orandadır.

Akbulut ve arkadaşlarının öğretmen, müftü-imam ve polislerde yaptıkları bir çalışmada, ortak diş fırçası ve jilet kullanımı gibi önemli bulaş yolları katılımcıların sadece \%18,4'ü tarafından bilinmiş ve aynı soruyu doğru yanıtlayanların sayısı eğitim sonrası \%97,4'e çıkmıştır (12).

Isparta'da erkek berberleri ile yapılan bir çalışmada, katılımcıların \%1,3'ünün kendisinde, \%6,3'ünün birinci dereceden yakınlarında hepatit B teşhisi olduğu, bazılarının hepatit B aşısı yaptırdığı saptanmıştır. Katılımcıların çoğu HBV'nin ortak kullanılan jilet ile bulaşabileceğinden dolayı her müşteride farklı jilet kullandığını belirtmiştir. Ancak berberlerin sterilizasyon dezenfeksiyon önlemleri açısında gereken önlemleri almada yetersizlikleri görülmüştür (13). Kadın berberleri ile yapılan anket çalışmasında ise, ortak kullanılan malzemelerde etkin bir dezenfeksiyon/sterilizasyon metodunun kullanılmadığı tespit edilmiştir $(14,15)$.

Yurtdışından bildirilmiş olan toplumun farklı kesimleri arasında yapılan çalışmalarda da benzer eğitim açığı saptanmış olup, sağlık çalışanları da dahil olmak üzere, enfeksiyondan korunma ve bulaş yolları hakkında eksik ya da yanlış bilgiye sahip olduğu gösterilmiş, yapılan eğitim çalışmaları ile konuya dikkat çekilmesinin aşılanma yolu ile enfeksiyondan korunmaya katkı sağladığı gösterilmiştir (16-18). ABD'de hastalığın endemik olduğu Asya bölgesinden gelen göçmenler arasında da hastalık hakkında yetersiz ya da yanlış bilgi düzeyi saptanmıştır (19).

Viral Hepatitle Savaşım Derneği (VHSD) önderliğinde 19 ilde yürütülen bir anket çalışmasında toplumda HBV enfeksiyonu ile ilgili bilgi düzeyi araştırılmış, 13873 kişiye ulaşılmış ve katılımcıların büyük çoğunluğunun hastalığın bulaş yolları, risk faktörleri ve korunma yolları ile ilgili bilgi düzeylerinin çok yetersiz olduğu saptanmıştır (20). Ülkemizde, Adana, Hopa ve Adıyaman illerinde, ailesinde hepatit B tanılı vaka olan hasta yakınlarının bilgi düzeyinin incelendiği çalışmada, 323 hasta yakınına 73 sorudan oluşan anket bire bir yanıtlatılmış. Katılan katılımcıların \%37'si aile bireyinde hepatit tespit edildiğini, \%10'u ise hastalığı geçirdiğini bildirmiş. Hastalık hakkında \%62 oranında sağlık çalışanlarından bilgi edindiğini ifade eden katılımcıların, \%74,9'u hepatit B'nin bulaşıcı bir hastalık olduğunu, \%78'i aşısı olduğunu belirtmiş. Hepatit B'li anneden doğan bebeğin doğumdan sonra en kısa sürede aşılanması gerektiğini ve bunun yenidoğana bulaşı engelleyeceğini bilme oranı \%54,5 olarak tespit edilmiş. Katılımcıların \%52,6'sı hepatit B hastalığının hepatit C'ye dönüşebileceğini belirtmiştir (21). Her ne kadar bu çalışma hasta yakınlarında yürütülmüş olsa da, çalışmamız sonuçları ile benzerlik göstermesi açısından önemlidir. Bu iki çalışmanın çalışmamız verileri ile karşılaştırılmalı sonuçlar Tablo 6'da sunulmuştur.

VHSD tarafından 32 ilde yürütülmüş olan eğitim kampanyalarının davranış değişikliğine katkısı da araştırımıştır. Ancak bu çalışmanın sonuçları değerlendirildiğinde konunun devamlı gündemde tutulmasının, sürekli eğitim çalışmaları ile davranış değişikliğinin sağlanabileceği sonucuna varılmıştır (22).

HBV ile enfekte hastalarla yapılmış çalışma olmamasından dolayı, benzer popülasyonda bilgi düzeyi karşılaştırması yapmak mümkün olamamakla birlikte, bilgi düzeyinin gerek toplumumuzda gerekse hastalarda ve hasta yakınlarında yetersiz olduğu açıkca görülmektedir. Toplumun eğitim düzeyindeki yetersizlik, bu hasta grubunun, sosyal hayatlarında da sıkıntı yaşamalarına sebep olmaktadır. Hastalık hakkında bilgi düzeyinin artırıması ve aşılama çalışmaları ile hastalığın hem görülme oranında azalma sağlamak, hem de bu tür sıkıntıların önüne geçmek mümkün olacaktır.

\section{Kaynaklar}

1. Perz JF, Armstrong GL, Farrington LA, Huntin YJ, Bell BP. The contribution of Hepatitis $B$ and Hepatitis $C$ virus infection to cirrhosis and primary liver cancer worldwide. J Hepatol. 2006; 45: 529-38. Epub 2006 Jun 23.

2. Lavanchy D. Hepatitis B virus epidemiology, disease burden, treatment and current and emerging prevention and control measures. J Viral Hepat 2004; 11: 97-107.

3. Goetz A, Yu CM, Muder RR. Microbiology, infection, control, immunizations and infectious disease exposure; education and practices in United States nursing schools. Am J Infect Control. 1992; 20: 115-21.

4. Mafany NM, Mati KJ, Nasah BT. Knowledge of and attitudes towards sexually transmitted diseases among secondary school students in Fako District Cameroon. East Afr Med J. 1990; 67: 706-11.

5. Moore- Caldwell SY, Werner MJ, Powell L, Greene JW. Hepatitis B vaccination in adolescents: knowledge, perceived risk and compliance. J Adolesc Health. 1997; 20: 294-9.

6. Nadeau D, Boyer R, Godin G, Manhès G, Fortin C, Duval B. Knowledge and attitude to sexually transmitted diseases and condoms in students and undergraduate students. Can J Public Health. 1993; 84: 181-5.

7. Kılınçer A, Coşkun M, Canbaz S, Dabak Ş, Pekşen Y. Ondokuz Mayıs Universitesi öğrencilerinin cinsel yolla bulaşan hastalılar hakkındaki bilgi düzeyleri. 6. Ulusal Halk Sağlığı Kongresi 14-18 Nisan 1998, Adana; 1998; s.439.

8. Çelen MK, Aygen B, Tekin-Koruk S, Karabay O, Tosun S, Koksal I, Turgut H, Onlen Y, Balık I, Tabak F. The characteristics of patients with chronic hepatitis B in Turkey. The 22nd Conference of the Asian Pacific Association for the Study of the Liver 16-19 Feb 2012, Taipei, Taiwan, 2012; p.95.

9. Tabak F, Ozaras R, Mete B, Alkim C, Fincancı M, Koçak F, Görenek L, Erdem L, Ozgunes N, Kumbasar H. Chronic hepatitis B in Istanbul, Turkey: the epidemiology and clinical features. The 22nd Conference of the Asian Pacific Association for the Study of the Liver 16-19 Feb 2012, Taipei, Taiwan, 2012; p.94.

10. Cheung J, Lee TK, The CZ, Wang CY, Kwan WC, Yoshida EM. Cross-sectional study of Hepatitis B awareness among Chinese and Southeast Asian Canadians in the Vancouver- Richmond community. Can J Gastroenterol. 2005; 19: 245-9.

11. Genç M, Pehlivan E, Özer F, Kurçer MA, Karaoğlu L. Lise öğrencilerinin Hepatit B hakkındaki bilgi ve tutumları. Turgut Özal Tıp Merkezi Dergisi. 2000; 7: 240-3.

12. Akbulut A, Felek S, Akbulut HH, Çelik I. Viral hepatitle savaşta toplum eğitimi. Viral Hepatit Dergisi. 1998; 2: 81-6. 
13. Kişioğlu AN, Öztürk M, Demirel R, Uskun E, Kırbıyık S. Isparta il merkezindeki erkek berberlerin hepatit b hakkındaki bilgi tutum ve davranışlarının değerlendirilmesi. SDÜ Tıp Fakültesi Dergisi. 2000; 7: 53-7.

14. Hıdıroğlu S, Karavuş M, Topuzoğlu A, Şalva T. Manikür- pedikür yapan kadın berberlerin hepatit B hakkındaki bilgi tutum ve davranıșları. TAF Prev Med Bull. 2006: 5; 276-86.

15. Şahin NH, Bilgiç D, Esen Ü, Çetinkaya R, Tozoğlu Z. Bayan kuaförü çalışanlarının hepatit B'ye ilișkin bilgi ve uygulamalarının belirlenmesi. TAF Preven Med Bull. 2009; 8: 147-54.

16. Chao J, Chang ET, So SK. Hepatitis B and liver cancer knowledge and practices among healthcare and public health professionals in China: A cross-sectional study. BMC Public Health. 2010; 10: 98-109.

17. Skinner SR, Imberger A, Nolan T, Lester R, Glover S, Bowes G Randomised controlled trial of an educational strategy to increase school based adolescent hepatitis B vaccination. Aust N Z J Public Health 2000; 24: 298-304.

18. McPhee SJ, Nguven T, Euler GL, Mock J, Wong C, Lam T, et al. Successful promotion of hepatitis $B$ vaccinations among Vietnamese- American children ages 3 to 18: result of a controllled trial. Pediatrics. 2003; 111: 1278-88.
19. Taylor VM, Seng P, Acorda E, Sawn L, Li L. Hepatitis B knowledge and practices among Cambodian immigrants. J Cancer Educ. 2009; 24: $100-4$.

20. Öztoprak N, Tosun S, Balık I, Tabak F, Saltoğlu N, Örmeci N, Şencan I, Güner R, Gürbüz Y. Toplumda hepatit B virüs enfeksiyonu ile ilgili bilgi düzeyinin araştıııması. X. Ulusal Viral Hepatit Kongresi 1-4 Nisan 2010, Antalya, 2010, s.123-124.

21. Inkaya AC, Demir NA, Balci M, Demir LS, Yümlü N, Çiftçi $H$, Demiraslan $\mathrm{H}$. Evaluation of knowledge of people living close proximity to patients with hepatitis B virus infection. American Association for the Study of The Liver Diseases's 61st Annual Meeting, Oct 29-Nov 2, 2010 Boston, Massachusetts, 2010, p.1955.

22. Saltoğlu N, Tosun S, Balık I, Tabak F, Örmeci N, Şencan I, Güner R, Öztoprak N, Gürbüz Y ve VHSD Bölge Temsilcileri. Halka ve hekimlere yönelik VHSD hepatit eğitim toplantılarının kişilerin hepatit B hakkında bilgi ve davranış değişikliğine etkileri. X. Ulusal Viral Hepatit Kongresi 1-4 Nisan 2010, Antalya, 2010, s.169-170. 